\title{
Systematic Procedure for Generating Operational Policies to Achieve Target Crystal Size Distribution (CSD) in Batch Cooling Crystallization
}

\author{
Abdul Samad, Noor Asma Fazli; Singh, Ravendra; Sin, Gürkan; Gernaey, Krist; Gani, Rafiqul
}

Publication date:

2011

Document Version

Publisher's PDF, also known as Version of record

Link back to DTU Orbit

Citation $(A P A)$ :

Abdul Samad, N. A. F., Singh, R., Sin, G., Gernaey, K., \& Gani, R. (2011). Systematic Procedure for Generating Operational Policies to Achieve Target Crystal Size Distribution (CSD) in Batch Cooling Crystallization. Abstract from 4th International Conference on Modeling, Simulation and Applied Optimization, Kuala Lumpur, Malaysia.

\section{General rights}

Copyright and moral rights for the publications made accessible in the public portal are retained by the authors and/or other copyright owners and it is a condition of accessing publications that users recognise and abide by the legal requirements associated with these rights.

- Users may download and print one copy of any publication from the public portal for the purpose of private study or research.

- You may not further distribute the material or use it for any profit-making activity or commercial gain

- You may freely distribute the URL identifying the publication in the public portal 


\title{
Systematic Procedure for Generating Operational Policies to Achieve Target Crystal Size Distribution (CSD) in Batch Cooling Crystallization
}

\author{
Noor Asma Fazli Abdul Samad ${ }^{1}$, Ravendra Singh ${ }^{2}$, Gürkan Sin $^{1}$, Krist V. Gernaey ${ }^{2}$ and Rafiqul Gani*1 \\ (1) Computer Aided Process-Product Engineering Center (CAPEC), Department of Chemical and Biochemical \\ Engineering, Søltofts Plads, Building 229, Technical University of Denmark, DK-2800 Lyngby, Denmark \\ (2) Center for Process Engineering and Technology (PROCESS), Department of Chemical and Biochemical \\ Engineering, Søltofts Plads, Building 229, Technical University of Denmark, DK-2800 Lyngby, Denmark
}

Batch cooling crystallization is one of the important unit operations involving separation of solid-liquid phases. Usually the most common crystal product qualities are directly related to the crystal size distribution (CSD). However the main difficulty in batch crystallization is to obtain a uniform and reproducible CSD. Therefore supersaturation control can be applied to drive the process within the metastable zone and thereby enhance the control of the CSD. Although this approach has been shown to produce high quality crystals, the set point operating profiles for the supersaturation controller are usually chosen arbitrarily or by trialand-error. Therefore there is a need for a systematic procedure to generate operational policy that guarantees the target CSD can be achieved. Furthermore, to predict the desired crystal morphology by means of model-based approaches, appropriate models covering the effects of the various operational parameters on the behavior of the crystals are necessary. That is, generic multi-dimensional model-based framework that covers a wide range of crystallization models and operational scenarios.

The objectives of this work are to develop a systematic procedure for generating operational policies to achieve target CSD for batch cooling crystallization. In this procedure, an analytical CSD estimator will be employed to generate an operational policy. The estimator is based on the assumptions of constant supersaturation and an operation that is dominated by size dependent growth. The generated operational policy provides the supersaturation set point and by maintaining the operation at this point, a target CSD is achieved. Different operational policies that yield the same target CSD are then generated and compared with the CSD performance. All the operational policies generated by analytical CSD estimators are in this way validated with closed loop control. Here the generic multi-dimensional model-based framework for batch cooling crystallization has been developed and integrated with the monitoring and control procedure. Through this generic multi-dimensional model-based framework, a "specific" model can be generated and be used for closed loop control to verify the operation policies. Finally the performance between simulation models and analytical estimators will be compared and the best performance will be analyzed in term of CSD obtained, mean size diameter and total crystal mass. In this paper, the application of systematic procedure is illustrated for the potassium dichromate case study.

Keywords: crystal size distribution (CSD), analytical CSD estimators, batch cooling crystallization

* Corresponding author (Email: rag@kt.dtu.dk, Tel. +45 45252882, Fax: +45 45932906) 